\title{
MIR200B Gene
}

National Cancer Institute

\section{Source}

National Cancer Institute. MIR200B Gene. NCI Thesaurus. Code C81753.

This gene is involved in the regulation of gene expression and plays a role in the development of hepatocellular, breast and cholangiocarcinomas. 